\title{
Fast Girls, Foreigners and Gls: An Exploration of the Discursive Strategies Through Which the Status of Pre-Marital (Hetero)sexual Ignorance and Restraint Was Upheld During the Second World War
}

\author{
by Jenny Hockey, Angela Meah and Victoria Robinson \\ University of Sheffield
}

Sociological Research Online 14(5)14

<http://www. socresonline.org.uk/14/5/14.html>

doi:10.5153/sro.2035

Received: 23 Jun 2009 Accepted: 13 Oct 2009 Published: 30 Nov 2009

\begin{abstract}
This paper explores contradictions within qualitative data gathered among women and men whose young adulthood coincided with the Second World War. These data were generated as part of an ESRC-funded project which investigated the making of heterosexual relationships cross-generationally. They suggest the co-existence of both a prevalent taboo or stigma associated with sexual knowledge and practice before and outside marriage, and personal experiences of precisely these engagements with embodied sexuality. Drawing on Charles Tilly's work, the paper argues that, when interrogated, these contradictions can reveal the strategies through which a creaky heterosexual consensus was shored up during a period of military upheaval that profoundly destabilised existing beliefs and practices. Tilly differentiated between academic historians who sought to reconcile 'very large structural changes' and the changing experiences of ordinary people' through either collectivist or individualist approaches to 'history from below'. Neither of these methods could yield an adequate account, in his view. However, the 'lay historians' who participated in our study combined collectivist and individualist perspectives, thereby providing a unique insight into an era when collective values and individual practices were often in tension with one another. As our participants spoke about their young adulthood, their data revealed the potency of local gossip which mobilised wider discourses of alterity or 'othering', so shoring up a consensual view of sexual mores, despite the prevalence of attitudes and practices that contravened it. What we argue, therefore, is that rather than a half-remembered, contradictory account of heterosexuality during the 1920s and 1930s, the data we gathered in the early 21 st century exemplifies precisely the discursive strategies of that period. In other words, these data shed light on the ways in which not only heterosexual norms, but also an entire, endangered system of distinctions based on class, gender and national identity was upheld.
\end{abstract}

\section{Keywords: Sexual Knowledge, Sexual Practice, Taboo, Stigma, Gender, History, Marriage, Pregnancy, Death, Second World War}

\section{Introduction}

1.1 The sociologist, Charles Tilly has asked how Europeans live 'the big changes', posing the question: 'In different European regions and eras, what were the connections - cause, effect or correlation - between very large structural changes such as the growth of nation states and the development of capitalism, on the one hand, and the changing experiences of ordinary people, on the other?' (1985:11). Since 2002 we have been asking the same questions of qualitative data we began gathering in East Yorkshire which describe the cross-generational making of heterosexual relationships within families ${ }^{[1]}$. Our data are highly 'local' to particular individuals, families, farms, villages, social housing estates. Yet, as participants describe the negotiation of everyday life, a bigger and historically-specific context is woven into their accounts (see Meah et al. 2008). Drawn from 22 families, 72 interviews and six focus groups, what light can these 'local' data shed on the wider context of heterosexuality as lived out during the Second World War? Are our data, in any sense, generalisable to the UK population as a whole and, in providing localised insight into 'mundane heterosexualities', can they speak to heterosexuality itself, as an institution, an identity, an experience and a practice (Jackson 1996:30)?

1.2 Tilly's (1984) concern with theories of historical social change provides a relevant resource for responding to these questions; in particular his views on the use of history, the critical role of time in effecting developments and the importance of time and place comparisons to arrive at generalizations. 
With respect to history as a discipline, Tilly (1985) identified a polarisation between the approaches of political history which examines large scale political, economic and military changes, and those of social history which concerns itself more with the detail of everyday lives. Social historians such as Hobsbawm and Rude argued that history must be written 'from below' in order to challenge representations of those who engage in collective action as a 'faceless, irrational crowd' (Tilly 1985:21). How history 'from below' is undertaken varies, however. In part it has been based on collective biographies within which patterned commonalities are sought; in part on individual case histories. In other words, some social historians can be described as 'collectivists', and others as 'individualists' (Tilly 1985:26). With regard to the

'individualists', Tilly describes them having 'abandoned the search for common properties and systematic variations in favour of the loving reconstruction of exemplary individual lives' (1985:24-25). Yet in his view, neither the social historians who espoused a 'collectivist' stance, nor those working from an 'individualist' perspective, provide adequate links between local stories and the big changes. Instead, collectivists and individualists, respectively, face the twin dangers of either making crude oversimplifications on the basis of small samples, or generating highly specific 'case histories' of individuals who 'illustrated some principle of revolutionary action, or who simply lived interesting lives' (1985:25).

1.3 What we draw from Tilly's engagement with social history - and social historians - is not so much the method he proposes, as a way of thinking about our participants' data. Like academic historians, they too offered accounts of the past. Rather than seeking evidence in records, archives or letters, however, their resources are personal memories, coupled with the prompts of fellow focus group participants, or the memorabilia to hand in their homes. But are they concerned with the same project that preoccupies academic social historians? It might seem that rather than historical reconstruction they are engaged in reminiscence, the well-documented practice of life review through which older people in particular attempt to make sense of earlier experience (Bornat 2005). What we argue, however, is that our participants can be seen as 'lay historians' who did not restrict themselves to reflecting on their personal life history. Rather than the narrowly individualist approach Tilly identifies in the work of Cobb, for example, these women and men had elected to participate in our study partly in order to inform us about a time that no member of the research team had experienced. Indeed Angela Meah, the researcher they worked with directly, was the youngest member of the research team at 29.

1.4 What we found, among the 'lay historians' who participated in our study, then, was evidence of both collectivist and individualist approaches. In other words, their responses to questions about adolescent and young adult experiences of heterosexuality during the 1920s and 1930s drew on their memories of collective attitudes to (hetero)sexual knowledge and experience, and neighbourhood responses to sexual transgressions. When they told us their personal histories, these were enmeshed in contextual accounts of appropriate heterosexual practice at that time, along with examples of individuals who had transgressed accepted norms, individuals who in some cases might be themselves. What struck us particularly were the contradictions within data that made repeated references to the taboo nature of pre-marital (hetero)sexual knowledge and experience at that time, whilst recounting evidence of young people's agency in acquiring not only sexual knowledge, but also opportunities.

1.5 What we explain in this paper is how Tilly's (1985) work has helped us work with these data. In interpreting a relatively small qualitative dataset made up of transcripts from 6 focus groups and 72 interviews, we were at pains to avoid the pitfalls of collectivist and individualist approaches, the trap of crude generalisations or over-interpreted case studies. Once we had recognised these two approaches within our data, however, and come to understand the status of our participants as lay historians, we were able to move forward with an interpretation that reveals the strategies through which a heterosexual consensus was shored up during a period of military upheaval that profoundly destabilised existing beliefs and practices. Combining our own data with published historical material, including both academic articles and the letters of servicemen and their female partners and families, allowed us to hear what it had to say about both local and larger-scale biographical and historical change and the ways in which these were not only informed by, but also influenced the negotiation of heterosexuality.

1.6 What follows, then, is an account of how we made sense of participants' responses to questions about sexual knowledge and practice during the time of their early adulthood which, as we show, encompassed the period of the Second World War. On the one hand, they stressed their lack of knowledge and their restraint within heterosexual relationships prior to marriage, shoring up their case through generalised comparisons between 'their day' and a contemporary world where sexual knowledge and practice was, in their view, unfettered. On the other hand, these accounts of social change contradict evidence of teenage pregnancy, extra-marital affairs, and children born within marriage to men other than their social fathers, to be found within our dataset. These accounts also contradict published histories which document considerable access to sexual knowledge and practice during this period. For example, MassObservation's 1949 'Little Kinsey' reports that 55\% of its National Panel had had pre-marriage sex relations, with only $17 \%$ of these restricting their relations to the person they went on to marry (Stanley 1995:134). Humphries' (1988) study of sexuality between 1900 and 1950 also documents the sex talk that took place, along with pregnancies outside marriage. With regard to the Second World War in particular, material written at that time, by, for example, a probation officer (see Norman, cited in Jeffreys 1989:7), made reference to the 'sexual incontinence' and 'shameless conduct' brought about by the changed circumstances of everyday life.

1.7 It might seem, therefore, that our data could be interpreted as an insight into attitudes rather than behaviours (Stanley 1995); or as socially acceptable stories that bear little relation to what actually happened; or the perspectives of an older cohort whose access to contemporary sexual mores was restricted to TV programmes about sex tourism in Ibiza, Aya Napa and other resorts; or indeed as a very partial, individual perspective that could not speak to the social, the general or the collective? When we linked the individual to the collective, however, combining participants' opinions and more extended case histories with published histories, we found that it was precisely the contradictions within individuals' data that spoke to the collective. Our data thus turned out to be particularly telling, rather than material to be 


\section{Studying social change 'from below'}

2.1 The research through which these data were generated explored processes of intra-familial, crossgenerational cultural transmission that oriented individuals in particular ways towards heterosexuality. To this end we carried out six focus groups within existing local organisations: a church group and an Adult Education group gave access to middle-class participants, while two day centre groups for older people, a women's group and a young men's group drew working-class participants. Four groups were single sex and two were made up largely of older adults. In these settings we conducted a 'quiz', comprising statements made about marriage, divorce and sex by people of different ages, speaking at different points in the twentieth century. Discussing these statements and seeking to locate them historically led participants to compare what was said with their own views and experiences at different points in their life course (Hockey et al. 2002). These data then informed life history interviews which were carried out with family members from three successive generations in 22 East Yorkshire families, 72 interviews of $1-5$ hours being recorded. Interviews were designed to focus on participants' childhood contexts, their experiences of finding out about sexuality and relationships, their engagement with dating, coupledom and family formation, and their key life course transitions such as marriage, divorce and the death of a partner. Importantly, participants were invited to reflect upon the 'heterosexual' lives of other family members. The sample of families reflected differences between East Yorkshire's rural population and Hull's urban environment. Less than half these participants were married or cohabiting at the time of interview (see Hockey et al. 2007 for further methodological detail ${ }^{[2]}$.

2.2 The data we gathered therefore derive from a relatively small sample, yet provide extensive personal and familial detail. They raise issues about the relationship between 'small stories' and the 'big picture'. In addition, as noted, they are internally contradictory. These contradictions emerge partly when the focus group and interview data are compared, focus groups lending themselves less to individual stories and more to generalising statements. But this distinction is by no means watertight and contradictions abound, both within focus group data and interview material as well as between these data and published histories and collections of letters. On the one hand, then, participants attest to the sexual naïveté of their youth and the taboo concerning sex outside marriage; on the other they acknowledge how, 'when the war came, it changed all sexual feelings and everything'. In what follows we offer a more nuanced account of the contexts of these contradictory statements and how they might reflect a public/private divide that is only partially mirrored in distinctions between focus groups and one-to-one interviews.

\section{Working across data sets}

3.1 Staying with the notion of contradictions - the apparent problem, we can identify the following dimensions of the period during and around the Second World War if we combine focus group and interview data with published histories and collections of letters. First, evidence repeatedly affirms a UK consensus that (hetero)sex before and outside marriage was conceived of as shameful and stigmatising during this period (see Day-Lewis 1995; Weeks 1989). Moreover, many of the older women we interviewed described the ways in which they were excluded from sexual knowledge or practice during this period. For example, they had very restricted access to private space for sexual activity as a result of parental supervision in the home (see Robinson et al. 2004), and could rent hotel space only through the subterfuge of a pretend marriage, a resort to which many young people's incomes would not stretch. Marion Ogden ${ }^{[3]}$, for example, describing her wedding night during the inter-war period, said:

'well, of course you enjoy it, don't you, yeah, $\mathrm{mm}$. Because that sort of thing, I mean, actually, of course in them days, I mean, you didn't get chance to sleep together anyway, so of course, naturally, you are looking forward to it, I should say, more so than what you maybe are now, because I mean ... you get more opportunities to be together now, don't you, than what you used to do then. I mean, like, a lot of people have flats and that now, don't they ... I mean, in them days, you never thought of anything like that'

[Marion Ogden, 85]

3.2 Moreover, neither parents nor teachers routinely provided any practical information about sexual practices of any kind (Robinson et al. 2004). As Jenny Hodge (67), said 'to be honest, l'd no idea how babies were born [.] when I had my first child'.

3.3 Second, the events of the Second World War brought changes in the availability of sexual knowledge and opportunities; for example, when women took on men's jobs in factories, public services and farming, when they volunteered or were conscripted into the Women's Auxiliary Airforce (WAAF) or the Auxiliary Territorial Service (ATS), when men were conscripted into active service abroad, when death in warfare or as a result of bombing became an imminent possibility, and when contact with 'foreigners', such as Gls and prisoners of war, became part of UK life. Based on testimonies which included the hundreds of letters she read in the Imperial War Museum, Day-Lewis (1995) says of this period: '[d] espite the danger, death, uncertainty and separation, it was a time when rules were broken, life was exhilarating' (1995:2). ' "War is a powerful aphrodisiac"', said one contributor to her study. These changes were not, however, evenly distributed among the population. Differences of gender, class, political allegiance and regional location shaped the extent to which war-time enabled or severed social relationships, gave access to sexual knowledge and opportunities, and brought exposure to death or bereavement. Moreover, these differential circumstances were by no means responded to consistently, again reflecting the social locations of particular individuals.

3.4 It is therefore within the context of a disjuncture, or fracture, between what ought to happen (the collectivist view) and what, for some, was happening (the individualist view) that young adults were growing 
up and forming heterosexual relationships and families. It is this context which needs to be taken into account when seeking to make sense of contradictions within our data. What these indicate is a range of responses to a social world within which a more consensual view of appropriate heterosexual practice came loose from the environment within which it had held sway. This context begins to make sense of our lay historians' shifts between a collectivist and individualist approach to the historical and biographical data they have available to them in the form of memories, some which might take the material form of a bereavement, a collection of letters, a child born prior to marriage, a set of wedding photos.

\title{
Local gossip and 'public knowledge'
}

4.1 What our participants described, in focus groups and interviews, was a local social world within which those found to be flouting a consensual view of heterosexual practice were likely to be stigmatised via the potency of neighbourhood gossip. At the time of the Second World War, this response to behaviours which contravened generally accepted sexual mores was an extension of the 'enormous pressures for sexual conformity' that Humphries (1988:17) describes in his account of British (sex-related) experience from the 1900s. In 1927, for example, 16 year-old miner's daughter, Ada Haskins, who became pregnant after first sex with a sailor who subsequently jilted her, felt compelled to keep her maternal status forever a secret from the child her mother raised as her brother (Humphries 1988:15-16). Within our own data set, Marion Ogden (85), described the experience of her sister getting herself 'in trouble' in 1929 (see Hockey et al. 2007: 119-120; Meah et al. 2004). In her mid-20s, Marion's sister had become pregnant by a married man while working in service. However, it was not until after the birth of the child that Marion's mother was told of this. Reeling from the shock, her mother's response was so extreme that she ostracised her daughter for over 15 years. Marion reports: 'my mam wouldn't have anything to do with my sister at all, she wouldn't let me go and see her or anything, how taboo and strict it used to be'. Instead, both she and her father ended up meeting Marion's sister in secret, unbeknown to the mother, although she did, eventually, find out what was happening.

4.2 Marion admitted that their mother's reaction was harsh, but also acknowledged that it was a reflection of a historical moment, prior to the mobility facilitated by the advent of war, a time when such events were met with hostility. She reflects:

\begin{abstract}
Marion: Of course, she was very upset about it, but then, if you come to think about it, I mean, I'm not sticking up for my sister any more, now, I used to stick up for my mum when I come to it, because I lived at home and I had to live with my mum, hadn't I? And not only that, in fairness to my mum, my sister hadn't been real fair, had she? She should have told my mother,
\end{abstract}

\section{AM: Rather than waiting 'til,}

Marion: Waiting right... to give her that shock. You see, it was to a married man, well, as it happened,

4.3 So powerful was the social response to the situation Marion's sister found herself in, that its impact could be felt five years later, when Marion herself was courting. Then 17, Marion had a boyfriend, Joe Black, whom she knew from the Methodist chapel she attended. The couple had been courting for some time before Joe took Marion home to meet his parents. She reflects:
Marion: The very first time he took me home, I'd been at a dance down on Edgerton Road with somebody, with another girl, there was a few of us used to go, and when l came outside, he used to be outside waiting for me. And, when my sister had this baby, his mother and father stopped him going out with me.

\section{AM: Oh no, because they thought you were all the same?}

\section{Marion: So that's how you were tret in them days. It was a real, I mean, that's what, it was a real shameful thing.}

4.4 But while acknowledging that her sister had brought shame on her family, Marion was, nonetheless, angry that it should still impact on her own life years later. Powerless to override Joe's parents' edict, she offered some resistance by refusing to attend chapel and questioning the basis of Christianity:

\section{AM: Can you remember how you felt then, when Joe Black's family...}

\begin{abstract}
Marion: Yes, I felt very bitter, I never went to the chapel any more... And he had a shop and, um, he asked me to go to the shop to see him, and I went to the shop to see him and he was as bitter as I was, course we was only in our teens, was only kids as you might say then, no, no, they wouldn't, never let it, and I never went to that chapel any more. I thought, well, if that was what I say Christianity, they did, they stopped him going, as though I could have done anything about it. It broke our family up, I'll tell you, broke our family up.
\end{abstract}

4.5 Our focus group data resonated with similar, if less extreme examples of concern with public scrutiny and a consciousness of neighbours 'peering' over shoulders and judging private behaviours. For example, in relation to couples cohabiting outside marriage during their youth, focus group participants attending a day centre for older people explained that:

Edna: Well, you never heard of it, I didn't, did you? [ . ]Did you?

Leah: No, [( )] 
Edna: [They were all married].

Leah: We never thought of [( )]

Edna: [Living together].

AM: ... What would people have thought of people like that that didn't get married? Was it a bit of a scandal?

Edna: Yes, there would,

Leah: Oh yes, the neighbours would be chattering [Laughs] ${ }^{[4]}$

[Focus Group 3]

This was reinforced by a participant in another group who pointed out that 'you wouldn't have dreamed of moving in with them. ... It would have been shameful'.

4.6 Similarly, when Angela Meah, the researcher, reported a story about an undiscovered wartime affair to retired professionals contributing to another focus group, one participant commented: 'Surprising that the neighbours never let on'.

\section{Fast girls, foreigners and Gls: the 'othering' of sexual practice}

5.1 When wartime is the focus for accounts of local gossip and stigma, the contradictions between what ought to happen and the kinds of experience that participants recounted became more marked. The attitudes expressed close to home, in neighbourhoods and families, were drawn from an existing repertoire of more pervasive, generalising public discourses. But in an environment where mobility - and military mobilisation - undermined familiar social and geographical distances between people from different countries and social classes, these endangered distinctions constituted precisely the classificatory paradigm through which the borders of respectable sexual practice could be demarcated. Within these discourses, then, those who failed to adhere to appropriate sexual mores were understood to be somehow different from the mainstream; that is, there was an 'othering' of such individuals, and this can be found across our entire data set. As the examples below indicate, the polarisation of women into 'good' and 'bad' categories (the virgin and the wife; the pure women and the prostitute) which had pervaded nineteenth century sexual classification (Vicinus 1977; Walkowitz 1982) was compounded by the symbolic efficacy of distinctions based on national identity and social class. Those whose practices had, or were deemed likely to contravene respectable sexual norms were therefore located within the following categories: women who undertook 'men's jobs' (war work or military service) and became exposed to inappropriate sexual knowledge and opportunity; 'foreigners', whether Gls who 'seduced' British women who were unmarried or the 'sweethearts' and wives of men away on active service, or older foreign women who acted in a similar role vis-à-vis servicemen posted abroad; lower class British women generally ('girls' who were 'common', 'fast', 'forward' or 'cheap') (see Skeggs 1997).

5.2 Thus focus group participants, in particular, were quick to comment on the 'respectability', or otherwise, of their wartime contemporaries, some reflecting with humour on the events of their youth, others adopting a more judgemental tone, depending on the social class position of the speaker. In exploring the forms of 'othering' present within our data, therefore, we find collectivist stereotypes being used. These not only tend to individualise examples of illegitimate sexual knowledge and practice; they also locate it outside the mainstream of 'respectable' white British society. What we argue, therefore, is that rather than a halfremembered, contradictory account of heterosexuality during the 1920 s and $1930 \mathrm{~s}$, the data we gathered in the early $21^{\text {st }}$ century exemplify precisely the discursive strategies of that period. That is to say, the ways in which not only heterosexual norms, but also an entire, endangered system of distinctions based on class, gender and national identity was upheld.

\section{Factory girls and cleaners}

5.3 Among the working class participants of a social housing estate-based women's group, memories of women's opportunities to undertake men's jobs and to meet men from outside their immediate locality, perhaps even from another country, were linked with sexual transgression. The reflective tone of their recollections of neighbourhood responses was marked by nostalgia, perhaps facilitated by their distance from the events in question:

Maggie: I mean, I know what I was, but there was a lot of girls, say between the war breaking out, 1939, they knew what everything was about because [.] they'd [been around a bit]

Audrey: [Been around a bit].

All: [LAUGHTER]

Maggie: I know because I worked in a factory and you listen to 'em talking,

(): God they had some good times.

Elaine: Yeah [LAUGHS]

Audrey: There were kids who lived down our street and their dads were in the army, but by 
'eck, they had a lot of uncles!

All: [LAUGHTER]

Elaine: American [LAUGHS]

Maggie: [QUIETLY] There were a woman (lived next door to me) when we was young he was coming home as a sailor was running out.

\section{All: [LAUGHTER]}

[Focus Group 1]

5.4 Elsewhere, however, among members of a group of retired professionals, their reflections were presented without nostalgia. Again, community, workplace, neighbourhood and family were the local contexts within which these more pervasive processes of disapproval, or 'othering', were brought to bear:

Mavis: There were good girls and bad girls, and that was the end of it. You were either a good girl or you were a bad girl, no grey in between.

Maureen: And you were thankful that you were not the mother of a bad girl.

Joyce: Yes. I think some people just mature at different stages, don't they? Some women are quite, not over-sexed, but very sexed. We had one in our office that went round every married man ( ). There was a cleaner, and a manager, she'd already cleaned his office, and he went in, and this girl went in, and she locked the door and they couldn't get out.

Mavis: And there was one who died in the act.

Joyce: () But that particular woman, her husband was at the mercy of the Japanese through the whole of the war and she took his allowance and everything, and the minute he arrived, she divorced him. I thought it was terrible, really.

\section{[Focus Group 2]}

These data clearly reflect a 'black and white' picture in which there are 'good and bad girls'; there is no room for 'grey'. The so-called 'bad girls', those who transgressed the sexual and social codes of the time, existed in spaces at the social fringe of these participants' worlds. They are the observed 'other' and their behaviours, therefore, are easier to reproach.

\section{Women in the military}

5.5 Those women who volunteered or, after 1941, were conscripted into military service were similarly seen to have access to inappropriate sexual opportunities. In a church-based group comprised of older women, one former member of the WAAF spoke indignantly, in response to these allegations that women in the WAAF had been promiscuous:

Pat: ...Some man said to me, some years ago, "Oh yes, WAAFs, well they were the airmen's blankets, weren't they?" I said, "No, they were NOT"

\section{All: [Laughter]}

Pat: I mean we had some nicer girls in the forces than some of those outside that I knew (emphasis added).

\section{(Focus Group 5)}

5.6 Our former WAAF participant went on to explain what the social implications were for those girls who did not have the 'sense' to stay away from men who expected to 'use them as blankets':

Pat: (...) Well, if you became pregnant, well, then you were in a heck of a mess, weren't you? And he wouldn't marry the girl, it was really tragic. We had one girl in the WAAF, (that's all) that I knew, and she was a very, very nice girl, she was lovely girl. And she got on with this (guy) that was supposed to be divorced, and he invited her to his home for the weekend to meet his family and then when his parents were out, he persuaded her to have sex with, and it was the first time she'd ever been with anybody, didn't want to, but then she gave in and she became pregnant. And she had to go into a mother and baby home to have this baby, and then have it adopted, and she was, she came from a very good home. Her mother was a widow, one of her brothers was a bank manager and another was something else. And I've often wondered how she went on. She was a lovely girl, you see, she brought shame on her family. US ${ }^{[5]}$

... A lot of families had them committed to mental hospitals.

From this excerpt it is clear that it was not just 'bad' girls whose reputations were at risk: even those who came from 'good' homes could bring shame on their families but, as we discuss below, this distinction was rarely made if 'shame' was brought on a family by a pregnancy outside marriage. 


\section{3. 'Common girls' and foreign military}

5.7 This category of 'girls', who were 'common', 'fast' or 'cheap', was mobilised to denigrate and 'other' those women who chose to respond to the sexual opportunities offered by the UK presence of men from a foreign military or prisoner of war camps. Thus one focus group discussed those 'girls' who, by inference, were not the 'nice' girls referred to above. These were women whose heads were turned by the appearance of the American servicemen whose money brought little luxuries otherwise unavailable to anyone except the wealthy. Clearly, these participants perceived the 'common girls' they spoke of as not belonging to their own social networks or groupings:

AM: So you were saying about all the visitors that came during the war, the American Gls and whoever. How did that accelerate people's knowledge and awareness, is it because they were a bit more forward?

Pat: They've always been the forward types.

All: $M m$.

US: The Americans, definitely, a lot more forward than our, (servicemen) in the forces.

US: There were always the girls who would be attracted to the Americans, wouldn't there?

US: Oh yeah.

AM And what were those girls like then?

US: (...) Well, (....) we used to term them 'common', didn't you?

US: Yes, yes, they were common.

All [Laughter]

US: Dead common.

US: If you were a little bit fast.

US: The Americans had a lot more, the servicemen had a lot more money to spend.

US: [Nylons].

US: [Chocolate].

US: [Cigarettes].

US: Certain girls would be attracted to that.

US: Nylons cost, well, you couldn't get them here, could you?

US: You had to put that stuff on your legs.

All [Laughter].

[Focus Group 5]

5.8 The notion of foreign men seducing British women also pervaded discussions in Focus Group 1, in which participants reflect on degrees of 'commonness' associated with the nationality of the servicemen:

AM: Going back, picking you up on something you were saying about the American soldiers being here during the war, by the sounds of it, there were plenty enough women that were,

Maggie: Oh yeah, there were.

Elaine: Well the men were away, sometimes for 3 or 4 years at a time if they were a prisoner o' war, they were alone, so o' course they wanted a good time, they had money in their purses.

Audrey: ... [lf you went with an America] you was common.

AM: If you?

Audrey: If you went out with an American you was common, that's the way they saw it.

Kathy: Isn't that being judgmental though?

Maggie: Not judgmental, because they was such boasters, what they had and what they hadn't. () was your own soldiers. 10 shillings a week, the Yanks were (puffing) up to the girls and buying nylons and cigarettes, 
AM: So would it have been different if you'd have been copping off, as we would say in Lancashire [LAUGHS], with British soldiers?

Audrey: Oh yeah. Then the Free French army came, and you was common as muck if you went with them.

(): [( )]

AM: God help you if you went with a German then! Was it you, Maggie, that told us about someone getting pregnant to an Italian,

Kathy: P.O.W., yeah

Maggie: My sister-in-law's sister, she nearly married a German prisoner o' war, and her mother forbade it.

[Focus Group 1]

These reflections are both vivid in the recollection of the memory of 'Yanks' 'puffing up' to local girls, flashing money that British soldiers did not have, but also in the social judgements made of the young women who were seduced by this. In spite of this vividness, it is noticeable that this is all observed behaviour and not something that any of these participants admitted to engaging in themselves.

\section{British men accessing sexual knowledge and experience overseas}

5.9 The distinction between 'good' and 'bad' girls and the unwillingness to admit shades of grey had implications in terms of sexual knowledge. In that such knowledge is at least in part embodied, 'good' girls were those without such knowledge, as Anita Smith (70) said, "I was as green as grass when I got married, I didn't know all the ....'. Similar points were made in a focus group discussion which referred to 'bad' girls as 'tarts':

AM So, thinking back to when you were 19, is that how things were? We've touched on this already, about couples not knowing how it was supposed to happen, were men expected to know more than women?

Elaine: Yeah, I think they did,

Audrey: [Yeah,]

Elaine: [If you knew, if you knew a lot about sex, you were looked upon as something of a [.] tart, or something,

Audrey: Yeah.

Maggie: I was right innocent.

Audrey: And things like this weren't talked about.

[Focus Group 1]

Again, we observe an anxiety among some of these participants to distance themselves from the 'negative' behaviours under discussion.

5.10 In circumstances in which women were expected to be 'good' or sexually naïve, men were expected to provide the know-how and take the initiative in sexual encounters. And in wartime, such knowledge was accessed most easily outside the immediate localities of home and family. As the excerpt below indicates, this typically occurred at the hands of older, more sexually knowing women:

Bob: In our generation, most of us would have been in the forces, and (will have been overseas and been around), I think you were a bit (more) experienced.

W (You had films to show you, didn't you?) [Laughs]

Bob: What would happen if you didn't behave yourself, it'd frighten you to death.

All: [Laughter]

Bob: ...l think most of us, certainly in the forces, were introduced to sex by an older woman.

And I think, to be truthful, there aren't many men that weren't seduced in our generation.

[Focus Group 2]

A similar observation is made by a participant in Focus Group 4, who reports that 'Well, when you were abroad, like, sex was there on a plate, like'. Quite literally, this again reinforces a perception of the sexually deviant 'other'. 
6.1 Via stigmatising local gossip which drew on more pervasive discourses of alterity or 'othering', a creaky consensus persisted, to be shored up in the post-war, welfare state's underwriting of the 'traditional breadwinner family', and the return of women to the constraints of domesticity. What we are describing, therefore, is a situation marked by fractures between public rhetoric and private practice. Yet it was no way a complete schism, another dimension of the environment which further complicates our reading of what happened during this period. Among the individuals most powerfully impacted upon by the Second World War, were the young women and men who met in the UK at the point when conscription meant separation for an unpredictable length of time and with an unknown outcome. For some couples, the tension between a consensual view of appropriate sexual and emotional practice prior to marriage and the feelings and desires which such relationships could inspire brought subsequent, lifelong regrets; couples who restrained themselves from practices such as penetrative sex risked never encountering this experience if death on active service was imminent. Alongside examples of women bereft of their partners during wartime within our data set, we can locate other sources which give powerful insights into the importance - and the costs, of sexual conformity for couples within which one partner failed to survive.

6.2 Day-Lewis (1995) gathered collections of wartime letters, many from the Imperial War Museum, and where possible - interviewed their writers or recipients. Betty Gibbs (70) met Stan Howard in 1941 at the Working Men's Club in West Thurrock, Essex when she was 16. A year later, Stan joined up as an airgunner in the RAF. When interviewed, Betty said that she 'refused to go to bed with him...I wanted to walk up to the altar with a white dress and not give in before I was married'. She went on:

\begin{abstract}
'A white dress symbolizes purity - I didn't want to let my mum down. Anyway, if l'd got a baby before I was married, I would have ended up in the workhouse. My mum and dad took me aside while I was courting Stan and told me they didn't want me to get into any "bothers" so I promised I wouldn't' (cited in Day-Lewis 1995:98).
\end{abstract}

In 1944 they got engaged and soon afterwards Stan wrote his first and last 'real love letter' home to her, one that for her evidenced a premonition of his death. A month after their engagement he was killed in the aftermath of a bombing mission. It was Betty's adherence to her parents' sexual requirements and her desire for the experience of wearing a 'pure' white wedding dress that resulted in the deferment of sexual activity between her and Stan.

6.3 Teenagers, Irene Sutton and Newton Oddy from Guildford had been 'courting' since 1942 and got engaged in 1944. Describing the leave during which they got engaged, Irene echoed Betty's statement when she said: 'We got very close on that December leave, it was becoming very difficult for him to behave himself. It wasn't looked on as very nice to make love before you were married then, if you went to the altar in a white dress, you had to earn the privilege' (cited in Day-Lewis 1995:117). In his letter the following April, after continuing to resist penetrative sex despite a brief episode in bed together, Newton wrote: 'Do you think it would be wise for us to go on holiday together? l'd try to control myself darling and you know that if you said "no" to anything, I wouldn't do it. I don't want you to have to put me in my place dearest because that would upset you and I don't want to do that' (cited in Day-Lewis 1995:119). Newton died in action a few days after his letter was written. When interviewed, Irene said, 'He was getting on for twenty, in the prime of his life. He died without knowing, he had never been with a woman. I regret it now, that was what he was wanting to do' (cited in Day-Lewis 1995:123).

6.4 The penalties of regret and grief experienced by women who survived these brief, teenage engagements without engaging in the sexual practices which they and their partners desired, have their counterpart in our own data set, for example, through the experiences of women such as 78 year-old Bernice Parr, who did become sexually active: Bernice became pregnant by a boyfriend who later died on active military service. As an unmarried 18 year-old mother-to-be, she attracted hostile responses. Here, she reflects on these:

\title{
"'Oh, she's one of them", you all got a bad name, whether it was the first time or whether you was a woman of the streets, you were all classed the same'.
}

6.5 Bernice's narrative indicates that this had not been a one-off 'fling', but that the couple had planned, or hoped, to be together once the war was over. Indeed, prior to his death, Bernice's sweetheart had sent money to support her and their son; this was stopped by his mother in the event of his death. However, although Bernice 'thought the end of the world had come', she says that, 'fortunately, my mother and father were very good, I had good parents, really, and they stood by me, you know'. For her, there was no question of the child being put up for adoption and she reported her mother stating that 'she would look after him while I went back out to work, and that's what we did'.

6.6 In different ways, then, the experiences of love and sexual desire during wartime could result in women being caught between the unenviable prospects of stigmatising gossip and potential lifelong regrets. By contrast, however, for some women these circumstances were recollected as period of empowerment as the discourses through which they were constrained could also be mobilised in ways that served women's own agendas. Jean Brown (74) was someone who engaged in sexual practice with her boyfriend, Harry, before their marriage, drawing on knowledge gleaned from surreptitious shared reading of her parents' copy of Marie Stopes Married Love (see Hockey et al. 2004). Jean married Harry in 1949, but their courtship was carried out during wartime. The excerpt below illustrates how the local presence of men in the forces from all parts of the world was, for her, a resource through which she secured her parents' consent to her liaison with a boyfriend four years older than she was.

AM: Was he the same age?

Jean: No, he was four years older than me. 
Jean: Not terribly well to begin with [LAUGHS], but my thing was, well, there's all these soldiers, sailors and airmen coming from all over everywhere, and, um, loads of my friends were going out with all these, you know, different nationalities and all sorts, and my argument was, well, at least you know him, you know his family, you know, and they sort of accepted it, and I said, you know, "Would you rather I went off to Bolton Palais?", you know, well, there were no Gls then, but I mean, there were all sorts, you know, and, so, they sort of accepted, you know, accepted him right away really.

6.7 Likewise, Stella Gold (78), similarly, was able to meet her own desires for social and romantic pleasure without attracting either stigma or regrets:

\section{Stella I always had these Canadian boyfriends.}

\section{AM: So how old would you have been then?}

Stella: I would be eighteen ... the officers came to the house, could they have a bath, oh we had a wonderful time with them, but they were there one day and gone the next.

\section{AM: So, I mean, were there any romantic attachments with any of these Canadians?}

Stella: Oh yes, I had a real romantic one with one, but he, er, and he used to take me out and we'd go to the cinema and for a drink and up to Whitby, but he was a total gentleman and, er, always brought me home safely.

6.8 Interestingly, Stella was able to have many 'boyfriends', and of different nationalities, but was not subject to disapproval for being either 'common' or 'bad' in the middle class rural community in which she lived. While it is not entirely clear from her data why she escaped this kind of local censure, she asserts that having these boyfriends did not involve her breaking with established sexual codes, something she attributes to her middle class upbringing. Unlike the girls who were seduced with gifts from the American Gl's described above, Stella describes receiving gifts from a Polish boyfriend in the Commandos:

'he took me out, but he was, er [...] extremely [.] polite man, I mean, he clicked his heels and bowed, you know, when he met you and [.] didn't quite kiss your hand but very nearly...'

6.9 There is an innocence and honour associated with courtship by this 'gallant' foreign man, which contrasts with her account of 'a boyfriend who was an Army, in the British Army Airborne Division' who failed to mention that he was already married. Stella responds to this omission properly, having stumbled upon it in conversation, enabling her to maintain her integrity as a 'good' girl. Here, Stella reports the decisiveness of her response:
'... so I said "well now look, I'm very sorry, I do like you but" I said "it's not fair on your wife, to take me out", so I stopped it all straight away so, you know, that's how we behaved in those days [...] so I never saw him any more'.

6.10 Stella is thus left with fond recollections of the good times she enjoyed with these boyfriends and her positive choices around the nature of her courtships. Rather than the agony of love and desire that could never be fulfilled once a fiancé had died in action, Stella is left with an account of her capacity to manage her experiences which reflects her social class position. Asked about expectations that "we might be dead tomorrow, so live for today", Stella said:

'Laissez faire?' [...] I think there was [...] um, there was but [.] I think in many respects, I'm talking for myself now, that I was in position that, of course I was on an isolated farm and I had my work to do, but this didn't come into my [.] er, my reckoning at all and being [.] middle class [.] you didn't deviate, you were brought up by your parents to have a code of conduct and you didn't, sort of, stray'.

Again, then, differences of social class mesh with distinctions between respectable and transgressive sexual practice. Stella's conformity to required sexual norms is something she understands in terms of her social class position.

\section{Conclusion}

7.1 The analysis we have presented in this paper is informed by Tilly's (1984) view that analyses require a concrete basis in real times, places and people as referents if the coherence of postulated structures and processes are to be tested against the experiences of real time, places and people. The accounts of 'real times, place and people' to be found within our data set cannot, we argue, simply be dismissed as the product of unreliable narrators or biased personal/individual historians. Instead these individual accounts can be read as 'lay histories' that encapsulate a collective experience of social change where a consensual view of appropriate sexual mores was no longer lived out consistently, yet through stigmatising and 'othering', its hegemony was sustained.

7.2 Though sex was something ' we never discussed', when practice was found to be at odds with a consensus view, this was precisely what was spoken of, in the 'public knowledge' of neighbourhood gossip. These were the contradictions which arose during the period of our participants' young adulthoods. It is precisely these contradictions which can be read out of their data, making their accounts and responses a valuable route into the collective via the local. The data therefore give us access to the 
consensus view or public rhetoric of the time; they evidence its somewhat patchy relationship with practice; and they detail the local-level strategies of gossip and 'othering' which reduced the capacity of practices that contravened public rhetoric to undermine that consensus. In the contradictions between social attitudes and emotional attachments/sexual behaviours we discover the scope of women and men to fall victim to stigma, grief and regret; we also access their capacities to draw upon these contradictions in ways that resourced personal agendas.

7.3 In this sense, the dangers faced by social historians who provide analyses that are either individualist or collectivist are overcome within these older women and men's accounts: in offering access both to generalising or collectivist perspectives that informed the imposition of restrictive sexual mores, and locating these alongside personal accounts of the possibilities and penalties associated with greater sexual knowledge and expanded practice, these accounts encompass precisely the tensions of a wartime period during which beliefs and practices were increasingly at odds with one another.

\section{Notes}

${ }^{1}$ We are grateful to the ESRC for their financial support for a project entitled $A$ cross-generational investigation of the making of heterosexual relationships (2001-2003).

${ }^{2}$ All focus groups and interviews were carried out by Angela Meah, referred to in data extracts as AM.

3 Pseudonyms are used throughout this paper to protect the anonymity of participants.

${ }^{4}$ The following is a guide to the nature and composition of the groups:

- Focus Group 1: Women's group (working class). 4 participants; aged late 30s to mid 70s.

- Focus Group 2: Adult education class (middle class). 34 participants, 10 men.; aged late 60 s to 80s.

- Focus Group 3: Older people attending a day-centre (working class); 7 participants, 3 men, aged early 70 s to mid 80 s.

- Focus Group 4: Older men attending a day-centre (working class); 6 participants; aged late 60s to early 80 s.

- Focus group 5: Women's church group (middle class). 10 participants; aged late 60s to 80s

5 US: Unidentified speaker

\section{References}

BORNAT, J. (2005) 'Listening to the Past: Reminiscence and Oral History', in M.Johnson, V.Bengtson, P.G.Coleman, T.B.L.Kirkwood (editors) The Cambrige Handbook of Age and Ageing. Cambridge: Cambridge University Press. [doi:10.1017/CBO9780511610714.031]

BURY, M. (2001) 'Illness narratives: fact or fiction', Sociology of Health and IIIness, Vol. 23, No. 3, pps. 263-285.

DAY-LEWIS, T. (editor) (1995) Last Letters Home. London: Macmillan.

HOCKEY, J., ROBINSON, V. and MEAH, A. (2002) '"For Better or Worse?" Heterosexuality Reinvented', Sociological Research Online, 7, 2. <http://www.socresonline.org.uk/7/2/hockey.html> [doi:10.5153/sro.728]

HOCKEY, J., MEAH, A. and ROBINSON, V. (2004) 'A Heterosexual Life: Older Women and Agency Within Marriage and the Family', Journal of Gender Studies, Vol. 13, No. 3, pp. 227-38.

[doi:10.1080/0958923042000287849]

HOCKEY, J., MEAH, A. AND ROBINSON, V. (2007) Mundane Heterosexualities. From theory to practices. Basingstoke, Palgrave.

HUMPHRIES, S. (1988) A Secret World of Sex. Forbidden Fruit: the British Experience 1900-1950, London: Sidgwick and Jackson.

JACKSON, S. (1996) 'Heterosexuality and Feminist Theory', in D.Richardson (editor) Theorising Heterosexuality. Buckingham: Open University Press.

MEAH, A., HOCKEY, J. and ROBINSON, V. (2008) 'What's sex got to do with it? A family-based investigation of growing up heterosexual during the twentieth century', The Sociological Review, Vol.56, No.3, pp.454-473. [doi:10.1111/j.1467-954X.2008.00799.x]

MEAH, A., ROBINSON, V. and HOCKEY, J. (2004) 'Narrating heterosexual identities: recollections, omissions and contradictions', in D.Robinson, C.Horrocks, N.Kelly, and B. Roberts (editors) Narrative, Memory and Identity, Huddersfield, University of Huddersfield Press. 
ROBINSON, V., HOCKEY, J. and MEAH, A. (2004) "What I used to do ... on my mother's settee": spatial and emotional aspects of heterosexuality in England', Gender, Place and Culture, Vol.11, No. 3, pp.417 435. [doi:10.1080/0966369042000258712]

SKEGGS, B. (1997) Formations of Class and Gender, London: Sage.

STANLEY, L. (1995) Sex Surveyed, 1949-1994. From Mass-Observations's 'Little Kinsey' to the National Survey and the Hite Reports. London: Taylor and Francis.

TILLY, C. (1984) Big Structures, Large Processes, Huge Comparisons. New York: Russell Sage Foundation.

TILLY, C. (1985) 'Retrieving European Lives', in 0.Zunz (editor) Reliving the Past. The Worlds of Social History. Chapel Hill: University of North Carolina Press.

VICINUS, M. (editor) (1977) A Widening Sphere: Changing Roles of Victorian Women. Bloomington: Indiana University Press.

WALKOWITZ, J. (1982) Prostitution and Victorian Society, Women, Class and the State. Cambridge: CUP. WEEKS, J. (1989) Sex, Politics and Society: the Regulation of Sexuality since 1800, London: Longman. 